\title{
SEASONAL INFLUENCE OF REED (PHRAGMITES AUSTRALIS) AND LOTUS (NELUMBO NUCIFERA) ON URBAN WETLAND OF YI RIVER
}

\author{
XU, S. Z. ${ }^{1}-$ WANG, Y. X. ${ }^{2}-$ WANG, Y. D. ${ }^{2}-$ ZHAO, Y. J. ${ }^{3}-$ GAO, Y. ${ }^{4 *}$ \\ ${ }^{1}$ Linyi No. 7 Middle School of Shandong Province, Linyi 276000, China \\ (e-mail:1306934800@qq.com) \\ ${ }^{2}$ Linyi No. 4 Middle School of Shandong Province, Linyi 276000, China \\ (e-mail: 327887987@qq.com; ykyyjyk@163.com) \\ ${ }^{3}$ College of Agriculture and Forestry, Linyi University, Linyi 276005, China \\ (e-mail: zhaoyanjie1882@126.com)
}

${ }^{4}$ Shandong Provincial Key Laboratory of Water and Soil Conservation and Environmental
Protection, College of Resources and Environment, Linyi University, Linyi 276005, China

${ }^{5}$ Linyi Scientific Exploration Laboratory, Linyi 276037, China

*Corresponding author

e-mail: gaoyuan1182@tom.com,gaoy@lyu.edu.cn

(Received 23 $3^{\text {rd }}$ Feb 2019; accepted $3^{\text {rd }}$ May 2019)

\begin{abstract}
Our research objective was to compare the eutrophication inhibition of reeds and lotuses on water body of wetland system of Yi River, evaluate ecological benefits of the two wetland systems, and reveal the response mechanism of water environmental factors, which not only has ecological theoretical significance, but also has extensive practical application value in the management and evaluation of wetland water ecosystem of Yi River. Three research sample plots were set up in Yimeng Lake of Yi River: reed water area, lotus water area and natural water area. In August (summer), October (autumn), December (winter) of 2018 and February 2019 (spring), subsurface water samples were collected and analyzed by laboratory detection for $\mathrm{pH}$, chromaticity, total hardness, dissolved oxygen, BOD, COD, ammonia nitrogen, total nitrogen, total phosphorus, nitrate and chlorophyll a. Research results were as follows: 1) $\mathrm{pH}$ appeared as that of lotus water area $>$ natural water area $>$ reed water area, chromaticity appeared as that of natural water area $>$ reed water area $>$ lotus water area. Total hardness appeared as that of natural water area $>$ lotus water area $>$ reed water area, dissolved oxygen appeared as reed water area $>$ lotus water area $>$ natural water area. BOD appeared as that of lotus water area $>$ natural water area $>$ reed water area, COD appeared as that of lotus water area $>$ natural water area $>$ reed water area. Ammonia nitrogen appeared as that of reed water area $>$ lotus water area $>$ natural water area, total nitrogen appeared as that of natural water area $>$ lotus water area $>$ reed water area, total phosphorus appeared as that of reed water area $>$ natural water area $>$ lotus water area, nitrate appeared as that of natural water area $>$ lotus water area $>$ reed water area, and chlorophyll a appeared as that of lotus water area $>$ natural water area $>$ reed water area. 2) $\mathrm{pH}$ appeared as that of winter $>$ spring $>$ summer $>$ autumn, chromaticity appeared as that of summer $>$ autumn $>$ winter $>$ spring. Total hardness appeared as that of winter $>$ autumn $>$ spring $>$ summer, dissolved oxygen appeared as that of spring $>$ summer $>$ winter $>$ autumn. BOD appeared as that of spring $>$ winter $>$ autumn $>$ summer, COD appeared as that of autumn $>$ summer $>$ winter $>$ spring. Ammonia nitrogen appeared as that of winter $>$ spring $>$ autumn $>$ summer, total nitrogen appeared as that of spring $>$ summer $>$ autumn $>$ winter, total phosphorus appeared as that of winter $>$ spring $>$ autumn $>$ summer, nitrate appeared as that of spring $>$ summer $>$ autumn $>$ winter, and chlorophyll a appeared as that of autumn $>$ summer $>$ spring $>$ winter. Our research conclusion is that reed can effectively increase dissolved oxygen and greatly reduce $\mathrm{BOD}, \mathrm{COD}$, total nitrogen, nitrate and chlorophyll a. Lotus can effectively increase $\mathrm{pH}, \mathrm{BOD}, \mathrm{COD}$, chlorophyll a, and greatly reduce total phosphorus. It is recommended to increase reed community area and try to expand lotus community in the water areas with severe phosphorus load.
\end{abstract}

Keywords: urban wetland, water quality, emergent plant, eutrophication, rubber dam, lacustrine river 


\section{Introduction}

Water eutrophication is an environmental problem that has aroused worldwide attention. A large amount of nutrients such as nitrogen and phosphorus of point source and non-point source pollutants enter the water body, which is an important cause of eutrophication (Schaffner et al., 2009; Zhang and Huang, 2011). The sensitivity of various water bodies such as rivers, lakes and reservoirs to eutrophication is closely related to hydrodynamic conditions and climatic conditions of the area where they are located. It is subjected to influence of hydrological, hydrodynamic, physical and chemical environmental factors and food web structures. Therefore, significant differences may exist between different water bodies and geographic locations (Li et al., 2012). Studies have shown that lakes and waters in the Asia-Pacific region are prone to eutrophication in various degrees, with $54 \%$ of water bodies exceeding the standard (Wang et al., 2012). Eutrophication degree of lakes in China is obviously higher than the average level in the Asia-Pacific region, and the water body over-standard-rate is up to $66 \%$ ( $\mathrm{Jin}$ and $\mathrm{Hu}, 2010$ ). At present, wetland water bodies like rivers and lakes have also entered the ranking of eutrophication, and the situation is increasingly serious (Ge et al., 2017).

Yi River, a large river in the Huaihe River Basin, is located in Southern Shandong and Northern Jiangsu, China, with geographical coordinates of $34^{\circ} 23^{\prime}-36^{\circ} 20^{\prime} \mathrm{N}$, $117^{\circ} 25^{\prime}-118^{\circ} 42^{\prime} \mathrm{E}$. About 574 kilometers long, it originates from Yiyuan County, Shandong Province, China, turns into Xinyi River (Yi River Diversion Canal) from Wulou Village, Peixian County, Jiangsu Province, China, and then flows into the Yellow Sea from Yanwei Harbor (Gao et al., 2008, 2009, 2010). Yi River is included in the "10th Five-Year Plan" on water pollution prevention and control in Huaihe River Basin for important control and monitoring. In the plan, the Chinese government points out that the plan is an important basis for the prevention and control of water pollution in the Huaihe River Basin of China, and that the economic construction activities in the Huaihe River Basin must meet the requirements of the plan. In 1997, the longest rubber dam in Asia was built in Xiaobudong, Linyi City section of Yi River, with a total length of $1,135 \mathrm{~m}$. After the successive completion of the stepped rubber dam, water volume in Linyi City section of Yi River increased significantly, and the original shallow wetland conditions changed as demonstrated by cyanobacteria blooms of Yi River urban section in 2009, 2011 and 2015.

A large number of studies have shown that aquatic plants, especially wetland plants, have positive significance in reducing water eutrophication (Huang, 2015). Reed (Phragmites australis) wetland is the world's main type of wetland, with a wide distribution and large coverage (Wang et al., 2018). It can treat wastewater through physical, chemical and biological functions (Zeng et al., 2012). Landscape plants or tool species introduced into European urban wetlands are mainly reeds (Korboulewsky et al., 2012), while reeds and lotus (Nelumbo nucifera) are widely present in urban wetlands in China (Ge et al., 2017). Lotus and reed have different ecological effects on wetland restoration. Comparing eutrophication inhibition of the two on water body of wetland system of Yi River, evaluating ecological benefits of the two wetland systems, and revealing the response mechanism of water environmental factors not only has ecological theoretical significance, but also has extensive practical application value in the management and evaluation of wetland water ecosystem of Yi River. 


\section{Materials and methods}

\section{Research basin overview}

The average annual precipitation of Yi River Basin is about $850 \mathrm{~mm}$, and the average annual evaporation from water surface is about $1100 \mathrm{~mm}$. There exists an urban wetland of about 3.6 square meters in Xiaobudong Rubber Dam and Jiaoyi Rubber Dam in Yihe City section, Taoyuan Rubber Dam and Liujiadaokou Hub - Yimeng Lake (Gao et al., 2008, 2009, 2010; Li and Gao, 2018).

\section{Water sample collection and detection}

In this field survey, three research sample plots were set up in Yimeng Lake of Yi River urban wetland: reed water area $\left(35^{\circ} 107^{\prime} \mathrm{N}, 118^{\circ} 324^{\prime} \mathrm{E}\right)$, lotus water area $\left(35^{\circ} 101^{\prime} \mathrm{N}, 118^{\circ} 351^{\prime} \mathrm{E}\right)$ and natural water area $\left(35^{\circ} 0811^{\prime} \mathrm{N}, 118^{\circ} 356^{\prime} \mathrm{E}\right)$. Three sets of duplicate plots were set for each plot, and three sets of duplicate water sample collection points were set for each plot, with one near shore, one in the center and one in the far shore. The sampling time was August 15 (summer), October 20 (autumn), December 16 (winter) of 2018 and February 142019 (spring). Sub-surface water samples (about 50 $\mathrm{cm}$ underwater) are collected for analysis and detection using $2.5 \mathrm{~L}$ clean water buckets.

In laboratory tests, $\mathrm{pH}$, chromaticity, total hardness, dissolved oxygen, $\mathrm{BOD}, \mathrm{COD}$, ammonia nitrogen, total nitrogen, total phosphorus, nitrate and chlorophyll a were analyzed. $\mathrm{pH}$ was measured by a portable waterproof $\mathrm{pH}$ meter (08533797) using glasselectrode method (GB-6920-1986). Chromaticity was determined by dilution factor method according to GB/T 11903-1989. Total hardness was determined according to GB/T 5750.4-2006 by EDTA titration. Dissolved oxygen (DO) was determined by electrochemical probe method according to HJ 506-2009. BOD (5-day biochemical oxygen demand) was determined by $25 \mathrm{~mL}$ acid burette (B193) using dilution and inoculation (HJ 505-2009) method. COD (chemical oxygen demand) was determined by $50 \mathrm{~mL}$ acid burette (B192) using dichromate method (HJ 828-2017). Ammonia nitrogen $\left(\mathrm{NH}_{3}-\mathrm{N}\right)$ and total phosphorus (TP) were determined by DR2008 visible spectrophotometer (1429121) using Nessler's reagent spectrophotometry (HJ 535-2009) and ammonium molybdate spectrophotometry (GB-11839-1989). Total nitrogen (TN) was determined by UV-1750ultraviolet-uisible spectrophotometer (A11605031003CS) using UV spectrophotometry (HJ 636-2012). Nitrate was determined by phenol disulfonic acid spectrophotometer according to GB/T 7480-1987. Chlorophyll a (Chla) was detected by acetone spectrophotometry according to HJ 897-2017.

\section{Results and analysis \\ Water quality evaluation}

According to the surface water environmental quality standard (GB 3838-2002), DO, $\mathrm{BOD}, \mathrm{COD}, \mathrm{NH}_{3}-\mathrm{N}, \mathrm{TN}$ and $\mathrm{TP}$ single indicators were used to evaluate the water quality of reed water area, lotus water area and natural water area of Yimeng Lake in different seasons. In China's surface water environmental quality standards, water quality grades are used to evaluate water quality. If the water level is high, that is the water quality is worse. I-II water is clean, IV water is contaminated, and super IV water is heavily polluted. 
In terms of DO, the reed water area has type III water in summer, autumn, winter and spring; the lotus water area has type III water in summer, type IV water in autumn, and type III-IV water in winter and spring; the natural water area has type III-IV water in summer and spring, type IV water in autumn and type III water in winter.

In terms of BOD, the reed water area has type IV-V water in summer and spring, and type V water in autumn and winter; the lotus water area has type V-inferior V water in summer, type $\mathrm{V}$ water in autumn and winter, and type IV waster in spring; the natural water area has type $\mathrm{V}$ water in summer, autumn and winter, and type IV water in spring.

In terms of COD, the reed water area has type III water in summer, type III-IV water in autumn, and type IV water in winter and spring; the lotus water area has type IV water in summer and autumn, and type III-IV water in winter and spring; the natural water area has type IV water in summer and autumn, and type III water in winter and spring.

In terms of $\mathrm{NH}_{3}-\mathrm{N}$, the reed water area has type II water in summer and spring, type III water in autumn, and type III water in winter; the lotus water area has type I-II water in summer, and type II in autumn, winter and spring.

In terms of TN, all of the reed water area, lotus water area and natural water area have inferior type $\mathrm{V}$ water in summer, autumn, winter and spring seasons.

In terms of TP, all of reed water area, lotus water area and natural water area have type I water in summer, autumn and spring, and type II water in winter.

\section{Seasonal dynamics of water environment factors}

Statistical analysis was performed on all data using SPSS 17.0 Chinese version.

$\mathrm{pH}$ characteristics of reed water area, lotus water area and natural water area (Fig. 1A). show: that of lotus water area $>$ natural water area $>$ reed water area $(p<0.01)$ in summer; that of lotus water area $>$ natural water area $>$ reed water area $(p>0.05)$ in autumn, with that of reed water area significantly lower than that of lotus water area and natural water area $(p<0.01)$; that of natural water area $>$ natural water area $>$ reed water area $(p>0.05)$ in winter; that of lotus water area $>$ natural water area $>$ reeds water area $(p>0.05)$ in spring.

Chromaticity characteristics of reed water area, lotus water area and natural water area (Fig. 1B) show: that of reed water area $=$ natural water area $>$ lotus water area $(p>0.05)$ in summer, with that of lotus water area significantly lower than that of natural water area and reed water area $(p<0.01)$; that of natural water area $>$ reed water area $>$ lotus water area in autumn, with that of lotus water area significantly lower than that of natural water area and reed water area $(p<0.01)$; that of natural water area $>$ reed water area $>$ lotus water area in winter, with that of lotus water area significantly lower than that of natural water area and reed water area $(p<0.01)$; that of reed water area $=$ lotus water area $=$ natural water in spring.

Total hardness characteristics of reed water area, lotus water area and natural water area (Fig. 1C) show: that of lotus water area $>$ reed water area $>$ natural water area in summer $(p<0.01)$; that of natural water area $>$ lotus water area $>$ reed water area in autumn $(p<0.01)$, that of reed water area $>$ natural water area $>$ lotus water area in winter $(p<0.01)$; that of natural water area $>$ lotus water area $>$ reed water area $(p>0.05)$ in spring.

Dissolved oxygen characteristics of reed water area, lotus water area and natural water area (Fig. 1D) show: that of lotus water area $>$ reed water area $>$ natural water area $(p>0.05)$ in summer, with that of lotus water area significantly higher than that of natural water area $(p<0.01)$; that of reed water area $>$ natural water area $>$ lotus water area in 
autumn $(p<0.01)$; that of reed water area $>$ natural water area $>$ lotus water area $(p>0.05)$ in winter, with that of lotus water area significantly lower than that of reed water area and natural water area $(p<0.01)$; that of reed water area $>$ lotus water area $>$ natural water area in spring, with that of reed water area significantly higher than that of lotus water area and natural water area $(p<0.01)$.

BOD characteristics of reed water area, lotus water area and natural water area (Fig. 1E) show: that of lotus water area $>$ natural water area $>$ reed water area $(p<0.01)$ in summer; that of natural water area $>$ lotus water area $>$ reed water area $(p<0.01)$ in autumn, with that of reed water area significantly lower than that of natural water area and lotus water area $(p<0.01)$; that of natural water area $>$ lotus water area $>$ reed water area $(p<0.01)$ in winter; that of reed water area $>$ lotus water area $>$ natural water area $(p<0.01)$ in spring.

COD characteristics of reed water area, lotus water area and natural water area $($ Fig. $1 F)$ show: that of lotus water area $>$ natural water area $>$ reed water area in summer $(p<0.01)$; that of natural water area $>$ lotus water area $>$ reed water area in autumn $(p<0.01)$, with that of reed water area significantly lower than that of natural water area and lotus water area $(p<0.01)$; that of reed water area $>$ lotus water area $>$ natural water area in winter $(p<0.01))$; that of reed water area $>$ lotus water area $>$ natural water area in spring $(p<0.01)$.

The characteristics of ammonia nitrogen in reed water area, lotus water area and natural water area (Fig. 1G) show: that of reed water area $>$ lotus water area $>$ natural water area $(p>0.05)$ in summer, with that of reed water area significantly higher than that of lotus water area and natural water area $(p<0.01)$; that of lotus water area $>$ reed water area $>$ natural water area in autumn $(p<0.01)$; that of reed water area $>$ lotus water area $>$ natural water area in winter $(p<0.01)$; that of reed water area $>$ natural water area $>$ lotus water area $(p>0.05)$ in winter.

The characteristics of total nitrogen in reed water area, lotus water area and natural water area $($ Fig. $1 H)$ show: that of lotus water area $>$ natural water area $>$ reed water area in summer $(p<0.01)$; that of natural water area $>$ lotus water area $>$ reed water area in autumn $(p<0.01)$; that of natural water area $>$ reed water area $>$ lotus water area in both winter and spring $(p<0.01)$.

The characteristics of total phosphorus in reed water area, lotus water area and natural water area (Fig. 1I) show: that of reed water area $>$ lotus water area $>$ natural water area in summer, with that of reed water area significantly higher than that of natural water area $(p<0.01)$; that of reed water area $=$ natural water area $>$ lotus water area in autumn; that of natural water area $>$ reed water area $>$ lotus water area in winter, with that of natural water area significantly higher than that of lotus water area $(p<0.01)$; that of lotus water area $>$ natural water area $>$ reeds water area $(p>0.05)$ in spring.

Nitrate characteristics of reed water area, lotus water area and natural water area show (Fig. 1J) show: that of lotus water area $>$ natural water area $>$ reed water area $(p<0.01)$ in summer; that of natural water area $>$ lotus water area $>$ reed water area in autumn $(p<0.01)$; that of natural water area $>$ reed water area $>$ lotus water area in winter $(p<0.01)$; that of lotus water area $>$ natural water area $>$ reeds water area $(p>0.05)$ in spring.

Nitrate characteristics of reed water area, lotus water area and natural water area show (Fig. $1 \mathrm{~K}$ ) show: that of lotus water area $>$ natural water area $>$ reed water area in summer, with that of reed water area significantly lower than that of lotus water area and natural water area $(p<0.01)$; that of lotus water area $>$ reed water area $>$ natural water area in 
autumn, with that of natural water area significantly lower than that of lotus water area and reed water area $(p<0.01)$; that of reed water area $>$ lotus water area $>$ natural water area in winter; that of lotus water area $>$ natural water area $>$ reeds water area $(p>0.05)$ in spring.
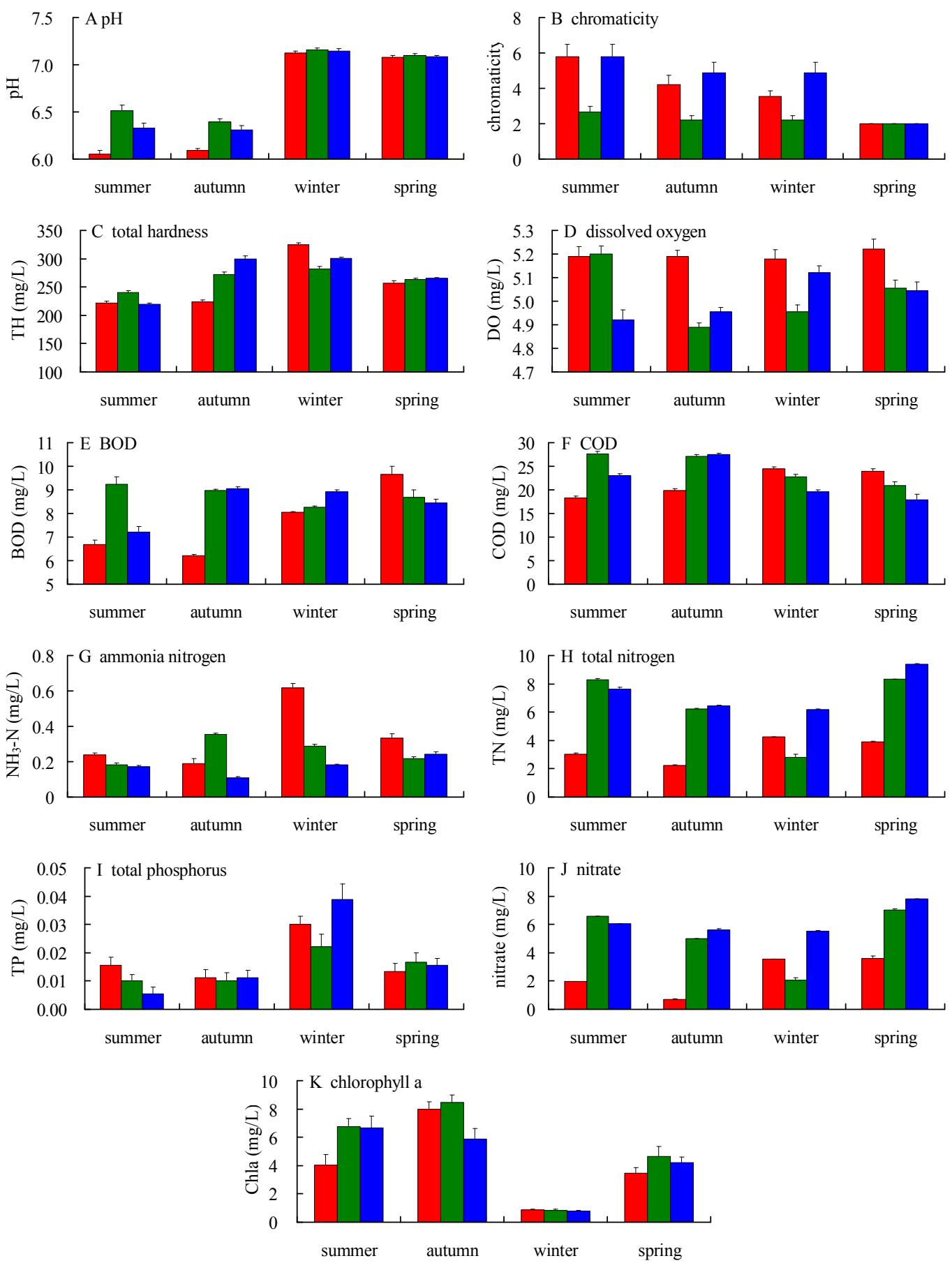

Figure 1. Differences $p H(A)$, chromaticity $(B)$, total hardness $(C)$, dissolved oxygen $(D), B O D$ $(E), C O D(F)$, ammonia nitrogen $(G)$, total nitrogen $(H)$, total phosphorus $(I)$, nitrate $(J)$ and chlorophyll a $(K)$ between water environment factors of reed water area, lotus water area and

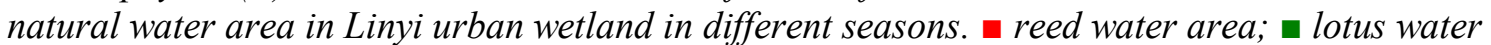
area; natural water area 


\section{Water environmental factor correlation}

The correlation between water environmental factors of reed water area (see Table 1) shows: $\mathrm{pH}$, total hardness, $\mathrm{BOD}, \mathrm{COD}$, ammonia nitrogen, total nitrogen, total phosphorus and nitrate are significantly positively correlated with each other $(p<0.01)$, and significantly negatively correlated with chlorophyll a $(p<0.01)$; chromaticity is significantly negatively correlated with total hardness and COD $(p<0.01)$.

Table 1. Relevance of water environmental factors of reed water area in Linyi urban wetland in different seasons, China

\begin{tabular}{c|c|c|c|c|c|c|c|c|c|c}
\hline & $\mathbf{p H}$ & $\mathbf{C H}$ & $\mathbf{T H}$ & $\mathbf{D O}$ & $\mathbf{B O D}$ & $\mathbf{C O D}$ & $\mathbf{A N}$ & $\mathbf{T N}$ & $\mathbf{T P}$ & $\mathbf{N I}$ \\
\hline CH & -0.31 & & & & & & & & & \\
TH & $0.98^{* *}$ & $-0.34^{*}$ & & & & & & & & \\
DO & -0.00 & 0.04 & -0.07 & & & & & & & \\
BOD & $0.90^{* *}$ & -0.22 & $0.86^{* *}$ & 0.02 & & & & & & \\
COD & $0.87^{* *}$ & $-0.51^{* *}$ & $0.88^{* *}$ & -0.06 & $0.81^{* *}$ & & & & & \\
AN & $0.92^{* *}$ & -0.32 & $0.90^{* *}$ & 0.04 & $0.87^{* *}$ & $0.81^{* *}$ & & & & \\
TN & $0.90^{* *}$ & -0.14 & $0.90^{* *}$ & -0.05 & $0.93^{* *}$ & $0.72^{* *}$ & $0.88^{* *}$ & & & \\
TP & $0.59^{* *}$ & -0.27 & $0.59^{* *}$ & -0.10 & $0.67^{* *}$ & $0.61^{* *}$ & $0.70^{* *}$ & $0.61^{* *}$ & & \\
NI & $0.87^{* *}$ & -0.16 & $0.87^{* *}$ & -0.06 & $0.89^{* *}$ & $0.69^{* *}$ & $0.89^{* *}$ & $0.98^{* *}$ & $0.61^{* *}$ & \\
Chla & $-0.68^{* *}$ & 0.25 & $-0.72^{* *}$ & 0.18 & $-0.73^{* *}$ & $-0.55^{* *}$ & $-0.75^{* *}$ & $-0.83^{* *}$ & $-0.56^{* *}$ & $-0.88^{* *}$ \\
\hline
\end{tabular}

$\mathrm{CH}$ : chromaticity; TH: total hardness; DO: dissolved oxygen; AN: ammonia nitrogen; NI: nitrate $* p<0.05 ; * *<0.01$

The correlation between environmental factors water of lotus water area shows (see Table 2): $\mathrm{pH}$ is significantly positively correlated with total hardness and total nitrogen $(p<0.01)$, and significantly negatively correlated with BOD, COD, total phosphorus, nitrate and chlorophyll a $(p<0.01)$; total hardness is significantly positively correlated with ammonia nitrogen and total phosphorus $(p<0.01)$, and significantly negatively correlated with dissolved oxygen, BOD, COD, total nitrogen, nitrate and chlorophyll a $(p<0.01)$; dissolved oxygen is significantly positively correlated with total nitrogen and nitrate $(p<0.01)$, and significantly negatively correlated with ammonia nitrogen $(p<0.01)$; BOD, COD, total nitrogen, nitrate and chlorophyll a are significantly positively correlated with each other $(p<0.01)$.

The correlation between water environment factors of natural water area shows (see Table 3): $\mathrm{pH}$ is significantly positively correlated with total hardness, BOD, dissolved oxygen, ammonia nitrogen and total phosphorus $(p<0.01)$, and significantly negatively correlated with COD, total nitrogen, nitrate and chlorophyll a $(p<0.01)$; total hardness is significantly positively correlated with BOD, dissolved oxygen and total phosphorus $(p<0.01)$, and significantly negatively correlated with total nitrogen, nitrate and chlorophyll a $(p<0.01)$; dissolved oxygen is significantly positively correlated with BOD and total phosphorus $(p<0.01)$, and significantly negatively correlated with COD, total nitrogen, nitrate and chlorophyll a $(p<0.01)$. BOD is significantly positively correlated with total phosphorus $(p<0.01)$, and significantly negatively correlated with ammonia nitrogen, total nitrogen, nitrate and chlorophyll a $(p<0.01)$; COD is significantly positively correlated with chlorophyll a $(p<0.01)$, and significantly negatively correlated with ammonia nitrogen and total phosphorus $(p<0.01)$. Ammonia 
nitrogen is significantly positively correlated with total phosphorus $(p<0.01)$, and significantly negatively correlated with chlorophyll a $(p<0.01)$. Total nitrogen is positively correlated with nitrate and chlorophyll a $(p<0.01)$, and significantly negatively correlated with total phosphorus $(p<0.01)$.

Table 2. Relevance of water environmental factors of lotus water area in Linyi urban wetland in different seasons, China

\begin{tabular}{c|c|c|c|c|c|c|c|c|c|c}
\hline & pH & CH & TH & DO & BOD & COD & AN & TN & TP & NI \\
\hline CH & -0.23 & & & & & & & & & \\
TH & $0.45^{* *}$ & -0.19 & & & & & & & & \\
DO & -0.24 & 0.20 & $-0.62^{* *}$ & & & & & & & \\
BOD & $-0.39 *$ & -0.19 & $-0.56^{* *}$ & 0.16 & & & & & & \\
COD & $-0.72 * *$ & -0.01 & $-0.57 * *$ & 0.31 & $0.727 * *$ & & & & & \\
AN & -0.02 & -0.31 & $0.59^{* *}$ & $-0.73^{* *}$ & -0.16 & -0.17 & & & & \\
TN & $-0.82^{* *}$ & 0.27 & $-0.75^{* *}$ & $0.55^{* *}$ & $0.58^{* *}$ & $0.78^{* *}$ & $-0.46^{* *}$ & & & \\
TP & $0.47^{* *}$ & -0.09 & $0.35^{*}$ & -0.01 & -0.25 & -0.35 & 0.17 & $-0.50^{* *}$ & & \\
NI & $-0.83^{* *}$ & 0.23 & $-0.73^{* *}$ & $0.52^{* *}$ & $0.59^{* *}$ & $0.79^{* *}$ & $-0.42^{*}$ & $1.00^{* *}$ & $-0.50^{* *}$ & \\
Chla & $-0.83^{* *}$ & 0.04 & $-0.47^{* *}$ & 0.01 & $0.67^{* *}$ & $0.81^{* *}$ & 0.10 & $0.75^{* *}$ & $-0.48^{* *}$ & $0.77^{* *}$ \\
\hline
\end{tabular}

CH: chromaticity; TH: total hardness; DO: dissolved oxygen; AN: ammonia nitrogen; NI: nitrate $* p<0.05 ; * * p 0.01$

Table 3. Relevance of water environmental factors of natural water area in Linyi urban wetland in different seasons, China

\begin{tabular}{c|c|c|c|c|c|c|c|c|c|c}
\hline & pH & CH & TH & DO & BOD & COD & AN & TN & TP & NI \\
\hline CH & -0.20 & & & & & & & & & \\
TH & $0.47^{* *}$ & -0.18 & & & & & & & & \\
DO & $0.58^{* *}$ & -0.13 & $0.413^{*}$ & & & & & & & \\
BOD & $0.39^{*}$ & -0.32 & $0.84^{* *}$ & $0.43^{*}$ & & & & & & \\
COD & $-0.75^{* *}$ & -0.12 & 0.06 & $-0.51^{* *}$ & 0.17 & & & & & \\
AN & $0.52^{* *}$ & 0.14 & -0.27 & 0.30 & $-0.37^{*}$ & $-0.79 * *$ & & & & \\
TN & $-0.55^{* *}$ & 0.26 & $-0.91^{* *}$ & $-0.57^{* *}$ & $-0.85^{* *}$ & 0.05 & 0.24 & & & \\
TP & $0.75^{* *}$ & -0.04 & $0.52^{* *}$ & $0.61^{* *}$ & $0.36^{*}$ & $-0.56^{* *}$ & $0.39^{*}$ & $-0.56^{* *}$ & & \\
NI & $-0.43^{*}$ & 0.10 & $-0.81^{* *}$ & $-0.43^{*}$ & $-0.77^{* *}$ & 0.04 & 0.21 & $0.83^{* *}$ & $-0.52^{* *}$ & \\
Chla & $-0.82^{* *}$ & 0.07 & $-0.53^{* *}$ & $-0.65^{* *}$ & $-0.43^{*}$ & $0.57^{* *}$ & $-0.40^{*}$ & $0.61^{* *}$ & $-0.67^{* *}$ & $0.40^{*}$ \\
\hline
\end{tabular}

CH: chromaticity; TH: total hardness; DO: dissolved oxygen; AN: ammonia nitrogen; NI: nitrate $* p<0.05 ; * * p<0.01$

\section{Discussion}

Studies in Wuliangsuhai Lake and Baiyangdian Lake show that lotus planting can significantly improve water quality and significantly inhibit the growth of algae in water bodies (He et al., 2013; Li et al., 2018), but attention should be paid to planting density as lotus has a hormesis effect on water algae ( $\mathrm{Li}$ and Hou, 2007). For reeds with good water purification effect, Dawen River wetland N shows net release when the reeds die and rot in winter, while P shows a net accumulation (Liu and Liu, 2012), which is contrary to our research result. In eutrophic ponds, the increase of total phosphorus 
decreases the relative abundance of annual plants without memory officer and increases the relative abundance of annual plants with memory officer (Arthaud et al., 2012). Eutrophication accelerates the decomposition of organic matter in plant litter (Deegan et al., 2012). Jinhewan Urban Wetland is the Driving Type of Total Nitrogen (Fan et al., 2012). Yihe urban wetlands with similar water environment background are also driven by total nitrogen.

\section{Conclusion}

Reed can effectively increase dissolved oxygen and greatly reduce BOD, COD, total nitrogen, nitrate and chlorophyll a. Lotus can effectively increase $\mathrm{pH}, \mathrm{BOD}, \mathrm{COD}$, chlorophyll a, and greatly reduce total phosphorus. In view of the fact that the current urban wetlands in Yihe River are mainly driven by total nitrogen nutrients. We think that the main controlled nutrient parameters of urban wetlands in Yihe River should be total nitrogen. It is recommended to increase natural and artificial reed community area and try to expand lotus community in the water areas with severe phosphorus load.

Acknowledgements. Funded by the Fund of Shandong Provincial Key Laboratory of Water and Soil Conservation and Environmental Protection, Linyi University, NO. STKF201906.

\section{REFERENCES}

[1] Arthaud, F., Vallod, D., Robin, J., Bornette, G. (2012): Eutrophication and drought disturbance shape functional diversity and life-history traits of aquatic plants in shallow lakes. - Aquatic Sciences 74: 471-481.

[2] Deegan, L. A., Johnson, D. S., Warren, R. S., Peterson, B. J., Wollheim, W. M. (2012): Coastal eutrophication as a driver of salt marsh loss. - Nature 490(7420): 388-392.

[3] Fan, X. C., Dai, C. F., Lu, X. X., Fan, Y. W. (2018): Studyonphytoplankton functional groups uccession and ddrivingparameters in the Jinhewan UrbanWe Tland. - Acta Ecologica Sinica 38: 5726-5738 (in Chinese).

[4] Gao, Y., Su, Y. X., Qi, S. C. (2008): Phytoplankton and evaluation of water quality in Yi River watershed. - Journal of Lake Sciences 20: 544-548 (in Chinese).

[5] Gao, Y., Ci, H. X., Qi, S. C., Su, Y. X. (2009): Seasonal changes of phytoplankton diversity and assessment of water quality in four tributaries of Yi River. - Research of Environmental Sciences 22: 176-180 (in Chinese).

[6] Gao, Y., Qi, S. C., Su, Y. X., Ci, H. X. (2010): Seasonal changes of phytoplankton diversity and water quality in Yi River and Beng River. - Transactions of Oceanology and Limnology 32(2): 109-113 (in Chinese).

[7] Ge, Z. W., Fang, S. Y., Li, C., Li, Q., Bu, Q. Q., Xue, J. H. (2017): Analysis of the plant $\mathrm{N}$ and $\mathrm{P}$ sequestration from common reed and common reed + cattail communities in wetland soil in Qinhu Lake of northern Jiangsu, China. - Journal of Lake Sciences 29: 585-593 (in Chinese).

[8] He, L. S., Meng, F. L., Meng, R., Huang, C. H., Li, Y. W., Xi, B. D., Shu, J. M. (2013): In Situ Enclosure Experiment on Nelumbo nucifera for Eutrophication Control in Baiyangdian Lake. - Wetland Science 11: 282-285 (in Chinese).

[9] Huang, X. Y. (2015): Biological cycling of nutrient elements of two plantations in southeast coastal area, China. - Journal of Northwest Forestry University 30(2): 84-89 (in Chinese). 
[10] Jin, X. C., Hu, X. Z. (2010): Concept and tactic of clean water runoff generation mechanism restoration in lake watershed. - China Environmental Science 30: 374-379 (in Chinese).

[11] Korboulewsky, N., Wang, R., Baldy, V. (2012): Purification processes involved in sludge treatment by a vertical flow wetland system: Focus on the role of the substrate and plants on $\mathrm{N}$ and $\mathrm{P}$ removal. - Bioresour Technol 105: 9-14.

[12] Li, D. L., Zhang, T., Xiao, T. Y., Yu, J. B., Wang, H. Q., Chen, K. J., Liu, A. M., Li, Z. J. (2012): Phytoplankton's community structure and its relationships with environmental factors in an aquaculture lake, Datong Lake of China. - Chinese Journal of Applied Ecology 23: 2107-2113 (in Chinese).

[13] Li, L., Hou, W. H. (2007): Inhibitory Effects of Liquor Cultured with Nelumbo nucifera and Nymphaea tetragona on the Growth of Microcystis aeruginosa. - Environmental Science 28: 2180-2186 (in Chinese).

[14] Li, X., Gao, Y. (2018): Influence of the island with grass and the island with trees to water quality in Yihe River, China. - Desalination and Water Treatment 121: 186-190.

[15] Li, X., Xu, X. Q., Gou, M. M. (2018): Study on the influence of lotus planting in Wuliangsu of Inner Mongolia on water environment. - Journal of Environment and Health 35: 457-459 (in Chinese).

[16] Liu, X. W., Liu, J. (2012): N and P dynamic of Phragmites australis and Typha angustata litter in Dawen River wetland during the decomposition. - Journal of Qingdao Agricultural University (Natural Science) 29(4): 289-293 (in Chinese).

[17] Schaffner, M., Bader, H. P., Scheidegger, R. (2009): Modeling the contribution of point sources and nonpoint sources to Thachin River water pollution. - Science of the Total Environment 407: 4902-4915.

[18] Wang, J. L., Li, Y. H., Li, F. D. (2018): Emission fluxes of $\mathrm{CO}_{2}, \mathrm{CH}_{4}$, and $\mathrm{N}_{2} \mathrm{O}$ from artificial and natural reed wetlands in Bosten Lake, China. - Acta Ecologica Sinica 38: 668-677 (in Chinese).

[19] Wang, Z., Zhang, Z. Y., Zhang, J. Q., Zhang, Y. Y., Yan, S. H. (2012): The fauna structure of benthic macro-invertebrates for environmental restoration in a eutrophic lake using water hyacinths. - China Environmental Science 32: 142-149 (in Chinese).

[20] Zeng, W. J., Liu, X., Liu, C. H., Chen, G. C., Liao, B. W. (2012): Comparison on purification effects of Sonneratia apetala and Phragmites communis wetland systems on nitrogen and phosphorus. - Ecological Science 31: 26-30 (in Chinese).

[21] Zhang, H., Huang, G. H. (2011): Assessment of non-point source pollution using a spatial multicriteria analysis approach. - Ecological Modeling 222: 313-321. 